\title{
ОСВОЄННЯ СУЧАСНИХ КЛІНІЧНИХ ПРОТОКОЛІВ МЕДИЦИНИ НЕВІДКЛАДНИХ СТАНІВ - СУТТЕВА СКЛАДОВА У ЯКІСНІЙ ПРАКТИЧНІЙ РОБОТІ БРИГАД ЕКСТРЕНОЇ (ШВИДКОЇ) МЕДИЧНОЇ ДОПОМОГИ
}

\author{
Р. М. Ляхович, Я. М. Кіцак, М. Я. Джус, В. І. Лях, Б. В. Дорошенко \\ ДВНЗ «Тернопільський державний медччний університет \\ імені І. Я. Горбачевського МОз Украӥни»
}

\begin{abstract}
У статті висвітлено проблемні питання з теоретичної підготовки та практичної діяльності працівників екстреної (швидкої) медичної допомоги. Зокрема, вказано на важливу роль в освоєнні ними сучасних клінічних протоколів, зроблено акцент на необхідності застосування прогресивних алгоритмів догоспітальної медичної допомоги із реалізацією як вітчизняних, так і зарубіжних протоколів. Розкрито інноваторську методику працівників кафедри екстреної та невідкладної медичної допомоги ДВН3 «Тернопільський державний медичний університет імені І. Я. Горбачевського МОЗ України».
\end{abstract}

\section{STUDY OF MODERN CLINICAL PROTOCOLS OF EMERGENCY MEDICINE - ESSENTIAL COMPONENT OF QUALITATIVE PRACTICAL WORK OF EMERGENCY MEDICAL SERVICE TEAMS}

\author{
R. M. Liakhovych, Ya. M. Kitsak, M. Ya. Dzhus, V. I. Liakh, B. V. Doroshenko \\ I. Horbachevsky Ternopil State Medical University
}

The article describes the problem questions of theoretical training and practical work of emergency medical service professionals. In particular it defines an important role of studying of modern clinical protocols, points on importance of progresive algorithms of prehospital emergency medical care with realisation of Ukrainian and foreign protocols. It describes an innovative methodology of work at the Department of Emergency Medical Care of I. Horbachevsky Ternopil State Medical University.

Вступ. Освоєння теоретичних знань з особливостей надання екстреної медичної допомоги бригадами «швидкої» $\epsilon$ важливою складовою в системі їхньої освіти, а, відтак, повсякденної практичної діяльності. Існує велика ймовірність, що якісне здобуття сучасної навчально-пізнавальної бази помножене на оволодіння практичних навичок у кінцевому результаті здатні суттєво підвищити загальний професійний рівень медичних працівників екстреної (швидкої) медичної допомоги (Е(Ш)МД). Саме з метою оптимізації діагностики та лікування гострих станів у світовій практиці існують так звані клінічні протоколи з «Медицини невідкладних станів» [1].

На теренах нашої держави до 2014 р. у роботі лікаря «швидкої» були впроваджені та діяли локальні протоколи, затверджені моз України наказом № 24, якими користувались впродовж останніх 9 років. Водночас, досвід показав, що з часом більшість з них застаріли, оскільки за цей період суттєво змінилися підходи до діагностики та надання екстреної догоспітальної медичної допомоги, оновився спектр медикаментозних засобів, обладнання, інструментарію тощо. Уніфіковані протоколи (наказ № 34), прийняті до виконання у 2014 р., за своєю структурою $є$ об'ємними, не охоплюють всіх базових невідкладних станів, які спостерігають в повсякденній роботі медиків Е(Ш)Мд і за своєю сутністю адаптовані до рівня освіти лікаря $[2,3]$. При цьому варто зазначити, що в Україні фельдшерські бригади становлять левову частину з усіх працівників «швидкої», а саме понад 70 \%. Все це змусило нас до пошуку універсальних та створення локальних клінічних протоколів, які ґрунтуються на сучасному світовому досвіді з урахуванням доказової медицини. Відрадно, що Український науково-практичний центр екстреної медичної допомоги та медицини катастроф рекомендує до введення в практичну діяльність

(c) Р. М. Ляхович, Я. М. Кіцак, М. Я. Джус, В. І. Лях, Б. В. Дорошенко, 2018 
Е(Ш)МД прогресивних міжнародних технологій з надання екстреної медичної допомоги на догоспітальному етапі, а також розроблених та затверджених на теренах нашої держави, стимулюючи на їх створення науковців та практичних лікарів.

Основна частина. При формуванні цих протоколів були взяті за основу рекомендації Європейської ради ресусцитації, де, зокрема, чітко розмежовують рівні догоспітальної медичної допомоги. Так, «Базова підтримка життя» (BLS) адаптована до освоєння знань немедичними працівниками (аварійних, рятувальних, інших екстрених служб та частини свідомого населення, яке проявляє бажання до цього навчання). Друга частина цих протоколів сформована на основі вимог програми «Розширена підтримка життя» (ALS), виконання якої відповідає фаховому стандарту «Парамедик» у США, Канаді, Великій Британії, Австралії, а також більшості країн Євросоюзу [4-6]. В Україні ці протоколи відповідатимуть навчальним програмам для лікарів усіх спеціальностей, які вивчають розділи медицини невідкладних станів, насамперед працівникам Е(Ш)МД, будучи при цьому корисними викладачам та студентам вищих медичних навчальних закладів [7-9].

На нашу думку, схема побудови загального (універсального) протоколу заходів екстреної медичної допомоги постраждалому в невідкладному стані може виглядати таким чином.

1. Оцінка місця пригоди.

Здійснити оцінку місця події, взявши за пріоритет особисту безпеку, і при відсутності такої в це середовище медичному персоналу не входити. Ця ситуація вимагає виклик допоміжних рятувальних служб (працівників МНС, поліції). Безпечне місце з наявністю декількох і більше постраждалих вимагає проведення швидкого первинного сортування за міжнародною системою START (чорні, червоні, жовті, зелені).

2. Огляд постраждалого та загальні заходи з надання екстреної медичної допомоги (дорослий або дитина).

3. Вжити заходи для попередження інфекційного впливу на медичного працівника. Зупинити масивну кровотечу, якщо вона наявна.

4. Виконати первинну оцінку стану постраждалого (прохідність верхніх дихальних шляхів, оцінку дихання, кровообігу) за АВС. Одночасно оцінити рівень свідомості за шкалою AVPU, де A - свідомість збережена, розмовляє; $\vee$ - порушення свідомості, реагує на голосний звук; P - порушення свідомості, реагує на грубі больові подразники; U - без свідомості, не реагує на стимуляцію болю. Оцінити шкірні покриви (температуру, колір, сухість, вологість, наявність висипань тощо). Оцінити капілярне наповнення (норма до 2 с).

5. За необхідності застосувати оновлену шкалу ком Глазго, де 15 балів - свідомість ясна, 14-13 балів приглушення, 12-10 балів - сопор, 9-8 балів - легка кома, 7-6 балів - кома середньої тяжкості, 5-4 бали глибока кома, 3 бали - позамежна, термінальна кома (смерть мозку).

6. Якщо у постраждалого наявні ознаки клінічної смерті - здійснити ЕКГ-діагностику виду раптової зупинки кровообігу (РЗК), а саме «ритми до дефібриляції» та «ритми не до дефібриляції». Негайно розпочати комплекс серцево-легеневої та мозкової реанімації із виконанням відповідної частини цього протоколу, усуваючи (виключно) в процесі лікування так звані « Г» та «4 Т».

7. При відсутності адекватного дихання проводити інгаляцію киснем через маску дихального мішка Амбу, або носову канюлю; відсутність дихання, поява патологічних типів дихання (Чейна - Стокса, Біота), частота дихання більше 40 та сатурація крові менше 90 \% є показаннями до інтубації трахеї (альтернатива встановлення ларингеальної маски чи ларингеальної трубки, чи комбітюба).

8. Застосувати іммобілізацію шиї/хребта, якщо для цього існують показання.

9. Зібрати анамнез постраждалого: ознаки/симптоми, що відчуває; алергія (чи є і на що саме); ліки (чи приймає постійно та які); захворювання та/або оперативні втручання в анамнезі; останній прийом їжі; подія, що передувала/викликала медичну проблему; що викликає (посилює) проблему; місце болю, іррадіація; важкість проблеми/болю; тривалість проблеми/болю.

10. Якщо постраждалий не належить до так званої категорії «Завантажуй та вези», провести швидкий огляд «з голови до п'ят», звертаючи увагу на наявність/відсутність деформацій, забоїв, саден, опіків, ран, набряку тощо. В іншому випадку, вторинне обстеження зазвичай виконують в кареті «швидкої» і має на меті виключення інших ушкоджень (захворювань). Деталізацію характеру ушкоджень опорнорухового апарату, ушкодження органів черевної та грудної порожнин, травми черепа здійснюють на госпітальному етапі!

11. Надавати медичну допомогу згідно з показаннями та протоколами, що застосовують до відповідних станів, з урахуванням віку та маси тіла постраждалого. 
12. Виконати ЕКГ у 12 відведеннях та підтримувати контроль за серцевою діяльністю згідно з показаннями.

13. Налагодити внутрішньовенне/внутрішньокісткове введення 0,9 \% фізіологічного розчину або розчину Рінгера із необхідною швидкістю відповідно до показань для віку/маси тіла постраждалого (за потреби - ще один венозний/внутрішньокістковий доступ та виконання правила «4 катетерів»).

14. Застосовувати ліки відповідно до показань та відповідного протоколу. Якщо є можливість, завжди запитувати постраждалого (родича) про алергію на медикаменти перед тим, як застосувати будь-який лікарський засіб.

15. Контролювати та перевіряти основні показники життєдіяльності постраждалого (ЧСС, ЧД, АТ, пульсоксиметрію, глюкометрію) кожні 3-5 хв постраждалому, який перебуває у нестабільному стані.

16. Розглянути потребу в додаткових ресурсах для надання повноцінної кваліфікованої ЕМД.

17. Визначити пріоритетність транспортування постраждалого в стаціонар. Пріоритетні стани включають: неможливість забезпечення прохідності дихальних шляхів; погіршення стану виглядає неминучим; шоковий стан; кровотеча, яку не вдається зупинити; порушення психічного стану, включно нерозуміння

\section{СПИСОК ЛІТЕРАТУРИ}

1. Екстрена та невідкладна медична допомога : підручник / [М. І. Швед, А. А. Гудима, С. М. Геряк та ін.] ; за ред М. І. Шведа. - Тернопіль : Укрмедкнига, 2016. - 448 с.

2. Про затвердження та впровадження медико-технологічних документів зі стандартизації екстреної медичної допомоги : наказ МОЗ України від 15.01.2014 р. № 34.

3. Богомолець О. В. Екстрена медична допомога (догоспітальні протоколи) / О. В. Богомолець, Г. Г. Рощін. - К. : Юстон, 2016. - 205 с.

4. Рощін Г. Г. Екстрена медична допомога (гострі серцеві стани) / Г. Г. Рощін, О. М. Пархоменко, В. О. Крилюк. - К. : ТОВ «НВП Інтерсервіс», 2011. - 138 с.

5. Білий В. Я. Алфавітний довідник з військової та екстремальної медицини / В. Я. Білий, О. О. Сохін. - 2-ге доповн. та випр. вид. - Ірпінь, 2013. - 298 с.

6. Рощін Г. Г. Методичні рекомендації для завідувачів кафедр невідкладної та екстреної медичної допомоги / Г. Г. Рощін, В. О. Крілюк. - К. : «Медицина», 2014 . - С. 3-18.

7. Медицина невідкладних станів: швидка і невідкладна медична допомога / І. С. Зозуля, А. В. Вершигора, В. І. Боб- простих команд; тяжке порушення дихання; ускладнені пологи; біль у грудях при систолічному АТ менше 100 мм рт. ст. У медичному сортуванні такі постраждалі зазвичай належать до категорії «червоні».

18. Відповідно до стану постраждалого та/або особливості травми/захворювання визначити необхідність у транспортуванні в найближчу лікарню або спеціалізований центр (відділення) ЕМД. Продовжувати підтримувальне лікування та контролювати основні показники життєдіяльності, допоки постраждалий не буде переданий на наступний рівень медичної допомоги [10-13].

Висновки. Правильний та сучасний алгоритм діяльності бригади Е(Ш)МД із використанням базових положень відповідного клінічного протоколу з медицини невідкладних станів на місці події передбачає врахування таких організаційних заходів: розпочати необхідне лікування без тривалих дискусій; передбачати наступний етап у процесі лікування; завчасно приготуватися до нього; працювати згідно з найкращими знаннями і рекомендаціями; бути професійним (колеги, родина); пам'ятати про юридичну відповідальність за надання (ненадання) медичної допомоги, тому максимально дотримуватись відповідного клінічного протоколу.

рова та ін. ; за ред. І. С. Зозулі. - К. : ВСВ «Медицина», 2012. - 728 c.

8. Екстрена та невідкладна медична допомога / М. І. Швед, А. А. Гудима, С. М. Геряк [та ін.]. - 2-ге вид. Тернопіль : Укрмедкнига, 2016. - С. 47-59.

9. Медицина неотложных состояний. Избранные клинические лекции / под ред. В. В. Никонова, А. Э. Феськова. - Д., 2008. - Т. 1. - 503 с.

10. Екстрена медична допомога: догоспітальний етап алгоритми маніпуляції (базовий рівень) / Г. Г. Рощін, А. А. Гудима, В. Ю. Кузьмін [та ін.]. - К., 2012. - 84 с.

11. Медицина надзвичайних ситуацій. Організація надання першої медичної допомоги : підручник / В. С. Тарасюк, М. В. Матвійчук, І. В. Паламар [та ін.]. - К. : «Медицина», 2011. - 526 с.

12. Кошелев А. А. Медицина катастроф. Теория и практика : учеб. пособ. - СПб. : «ЭЛБИ-СПб», 2015. - 320 с.

13. Соков Л. П. Курс медицины катастроф : учебник / л. П. Соков, С. Л. Соков. - М. : Изд-во РУДН, 2015. - 328 с. 